\title{
The glucagon-producing alpha cell: an electrophysiologically exceptional cell
}

\author{
M. Braun • P. Rorsman
}

Received: 22 April 2010 /Accepted: 19 May 2010/Published online: 16 June 2010

(C) Springer-Verlag 2010

\begin{abstract}
Activation of potassium channels normally serves to reduce cellular activity but recent data indicate that the glucagon-secreting alpha cells are different in this respect and that inhibition of voltage-gated potassium channels results in a paradoxical inhibition of glucagon secretion. Here we discuss these findings and attempt to provide a model for the regulation of glucagon secretion that incorporates these observations.
\end{abstract}

Keywords Alpha cells · Glucagon · Ion channels .

Pancreatic islets $\cdot$ Voltage-dependent inactivation

\author{
Abbreviations \\ $\left[\mathrm{Ca}^{2+}\right]_{\mathrm{i}} \quad$ Cytoplasmic free calcium concentration \\ $\mathrm{Ca}_{\mathrm{V}}$-channel Voltage-gated calcium channel \\ $\mathrm{K}_{\mathrm{ATP}}$-channel ATP-regulated potassium channel \\ $\mathrm{K}_{\mathrm{V}}$-channel Voltage-gated potassium channel \\ $\mathrm{Na}_{\mathrm{V}}$-channel Voltage-gated sodium channel \\ TEA Tetraethylammonium
}

\section{Introduction}

Glucagon is the body's principal blood-glucose-increasing hormone. It is released from the alpha cells of the pancreatic islets in response to a fall in blood glucose concentration, an increase in circulating non-esterified fatty acids and neurotransmitters and hormones such as adrenaline [1]. The regulation of glucagon secretion is currently

M. Braun $\cdot$ P. Rorsman $(\bowtie)$

Oxford Centre for Diabetes, Endocrinology and Metabolism,

University of Oxford, Churchill Hospital,

Oxford OX3 7LJ, UK

e-mail: patrik.rorsman@drl.ox.ac.uk hotly debated. According to one school, glucagon secretion is controlled by intrinsic mechanisms exerted within the alpha cell itself [2]. A second school postulates that glucagon secretion is under paracrine control and determined by factors released from the neighbouring beta or delta cells [1]. Of course, the two models need not be mutually exclusive and it is possible that glucagon secretion is regulated by a combination of intrinsic and paracrine mechanisms. In addition to the intrinsic and paracrine regulation, there is also evidence for hypothalamic regulation of glucagon secretion mediated via nerve branches ending within the islets [3]. However, such regulation cannot operate after isolation of the islets (when all nerve endings have been severed).

\section{Properties of alpha cell electrical activity: role of ATP-regulated potassium channels and voltage-gated calcium channels}

Like the beta cell, the alpha cell is electrically active and glucagon secretion is triggered in response to the firing of alpha cell action potentials $[1,2]$. The action potentials lead to the activation of voltage-gated calcium channels $\left(\mathrm{Ca}_{V}\right.$-channels) and result in the elevation of cytosolic $\mathrm{Ca}^{2+}\left(\left[\mathrm{Ca}^{2+}\right]_{i}\right)$, which culminates in exocytosis of the glucagon-containing secretory granules [4]. Several types of $\mathrm{Ca}_{V}$-channel contribute to the generation of the alpha cell action potential $[5,6]$.

The alpha cells also contain a variety of potassium channels. In general, opening of potassium channels reduces electrical excitability, whereas closure of these promotes excitability. For example, in the beta cell, the inhibition of the ATP-regulated potassium channels $\left(\mathrm{K}_{\mathrm{ATP}^{-}}\right.$ channels) that occurs in response to glucose stimulation produces membrane depolarisation, the initiation of action 
potential firing and stimulation of $\mathrm{Ca}^{2+}$-influx and insulin secretion [7].

Like the beta cell, glucagon-secreting alpha cells are equipped with $\mathrm{K}_{\mathrm{ATP}}$-channels [8]. Experiments in which increasing concentrations of tolbutamide and diazoxide (a blocker and an activator of the $\mathrm{K}_{\mathrm{ATP}}$-channel, respectively) were used to titrate $\mathrm{K}_{\mathrm{ATP}}$-channelsactivity in alpha cells in intact mouse, rat and human islets indicate that glucagon secretion only occurs within a narrow window of $\mathrm{K}_{\mathrm{ATP}}$ channel activity [9]. Glucagon secretion was suppressed both when $\mathrm{K}_{\mathrm{ATP}}$-channels were maximally activated by a high concentration of diazoxide and when channel activity was abolished by a high concentration of tolbutamide. These experiments suggest that glucose may inhibit glucagon secretion by exerting a tolbutamide-like effect on $\mathrm{K}_{\mathrm{ATP}}$-channel activity. Indeed, the alpha cells are equipped with many of the proteins involved in the metabolic glucose sensing of the beta cell, including glucokinase [10]. Glucose has also been shown to increase the intracellular concentration of ATP in alpha cells [11].

\section{Membrane potential-regulated potassium channels in alpha cells}

In addition to the $\mathrm{K}_{\mathrm{ATP}}$-channels, whose activity is not much influenced by the membrane potential, the alpha cells express voltage-gated potassium channels $\left(\mathrm{K}_{\mathrm{V}}\right.$-channels) that open in response to membrane depolarisation during the action potentials and are responsible for repolarisation of the membrane potential. In beta cells, blocking the $\mathrm{K}_{\mathrm{V}^{-}}$ channels leads to a prolongation of the action potentials and stimulation of insulin secretion [12, 13] (but see [14]).

In this issue of Diabetologia, Spigelman et al. [15] report on the effects of blocking the $\mathrm{K}_{\mathrm{V}}$-channels in alpha cells. Human and mouse alpha cells were found to be equipped with two types of $\mathrm{K}_{\mathrm{V}}$-channels: large-amplitude calciumactivated potassium channels (maxi-K channels) and smallamplitude delayed rectifying $\left(\mathrm{K}_{\mathrm{V}} 2.1\right.$ or $\left.\mathrm{K}_{\mathrm{V}} 2.2\right) \mathrm{K}_{\mathrm{V}}$-channels. In addition, the authors occasionally observed a transient $\mathrm{K}_{\mathrm{V}}$-current similar to the A-current previously documented in mouse alpha cells [16].

Spigelman et al. show that inhibition of the $\mathrm{K}_{\mathrm{V}}$-channels, rather than stimulating glucagon secretion as expected, led to a paradoxical inhibition of glucagon secretion. It is very difficult to record spontaneous electrical activity from alpha cells. Spigelman et al. were therefore obliged to use electrical stimulation to evoke action potential firing. This is a well-established 'trick of the trade' and the properties of the action potentials evoked by current injection are generally assumed to be the same as those occurring spontaneously. The authors found that it was only possible to initiate action potentials from a membrane potential between -60 and $-40 \mathrm{mV}$ and that sustained depolarisation beyond $-40 \mathrm{mV}$ resulted in a dramatic decrease in the amplitude of the action potentials $(20 \%$ of the maximum value at $-30 \mathrm{mV}$ ). They also found that electrical activity was (surprisingly) reduced in alpha cells after inhibition of the $\mathrm{K}_{\mathrm{V}}$-channels with tetraethylammonium (TEA) but that regenerative action potential firing could be restored by injection of hyperpolarising current. This is a key observation and illustrates the importance of membrane repolarisation mediated by activation of $\mathrm{K}_{\mathrm{V}}$-channels in alpha cell regenerative electrical activity. Collectively, the findings now reported by Spigelman et al. add to previous data [9] suggesting a complex relationship between the membrane potential of the alpha cell and electrical activity/glucagon secretion.

\section{Why does inhibition of $K_{V}$-channels inhibit alpha cell electrical activity and glucagon secretion?}

Voltage-gated ion channels typically exhibit a dual dependence on voltage [17]. Whereas brief depolarisation leads to increased activity ('activation'), sustained depolarisation makes the channels enter a non-conducting state ('inactivation'). Once the channels have entered the inactivated state, they must experience a brief period of negative voltage to reactivate and regain the capacity to open. Action potential firing in mouse alpha cells depends on activation of voltage-dependent sodium channels $\left(\mathrm{Na}_{\mathrm{V}}\right.$-channels) $[9$, 16]. The $\mathrm{Na}_{\mathrm{v}}$-channels contribute to the upstroke of the alpha cell action potential and their significance to glucagon secretion is illustrated by the finding that the $\mathrm{Na}_{V}$-channel blocker tetrodotoxin is a strong inhibitor of glucagon secretion. $\mathrm{Na}_{\mathrm{v}}$-channels undergo very rapid inactivation $(1-10 \mathrm{~ms})$ when the membrane potential exceeds $-60 \mathrm{mV}$ and become fully inactivated at $-35 \mathrm{mV}$ [16]. Because of their significance to the upstroke of the alpha cell action potential, graded membrane potentialdependent inactivation of the $\mathrm{Na}_{\mathrm{V}}$-channels can be expected to reduce the amplitude of the alpha cell action potential. Indeed, the range of voltages over which the $\mathrm{Na}_{\mathrm{V}}$-channels inactivate overlaps the membrane potential dependence of the action potential amplitude now reported by Spigelman et al.

\section{Action potential firing, calcium influx and glucagon secretion}

Neither pharmacological inhibition of $\mathrm{K}_{\mathrm{V}}$-channels nor voltage-dependent inactivation of $\mathrm{Na}_{V}$-channels suffices to explain the inhibition of glucagon secretion by TEA. As explained above, glucagon secretion depends on calcium- 
dependent exocytosis. In mouse alpha cells, exocytosis in alpha cells is negligible at membrane potentials more negative than $-20 \mathrm{mV}$ but increases steeply at more depolarised voltages [9]. This behaviour reflects the membrane potential-dependent opening of the $\mathrm{Ca}_{V}$-channels mediating the calcium entry that triggers exocytosis (Fig. 1a). A decrease in action potential amplitude (for example, resulting from inactivation of the $\mathrm{Na}_{\mathrm{V}}$-channels) will therefore result in fewer $\mathrm{Ca}_{\mathrm{V}}$-channels opening and this in turn means that fewer glucagon-containing granules undergo exocytosis (Fig. 1b, c).

The scenario outlined above rests principally upon data from mouse alpha cells. A more detailed characterisation of the ion channels, their voltage dependence of activation and inactivation and the relationship between membrane potential and exocytosis in human alpha cells is required to extend these findings to the regulation of glucagon secretion in humans. Nevertheless, the finding that $\mathrm{K}_{\mathrm{V}^{-}}$ channel blockers like TEA and iberiotoxin (the latter being a highly selective blocker of large-amplitude calciumactivated potassium channels) inhibit rather than stimulate glucagon secretion from both human and mouse islets argues that similar mechanisms operate in the alpha cells of both species.

\section{Coda}

Finally, these observations raise the interesting possibility that modulation of $\mathrm{K}_{\mathrm{V}}$-channels in alpha cells is involved in the physiological regulation of glucagon secretion. For example, zinc ions have been reported to inhibit the A-type $\mathrm{K}_{\mathrm{V}}$-channels in neurons [18]. If the $\mathrm{K}_{\mathrm{V}}$-channels in alpha cells are similarly affected, then zinc ions co-released with insulin will suppress glucagon secretion via inhibition of $\mathrm{K}_{\mathrm{V}}$-channels and alpha cell electrical activity. This would explain the reported inhibitory effects of zinc ions on glucagon secretion [19].

There have been several recent studies devoted to the regulation of glucagon secretion by glucose but the mechanisms involved remain enigmatic. The recent demonstration that glucagon secretion is inhibited from isolated mouse islets without any major effect on the cytosolic calcium concentration in the alpha cell [20] is difficult to

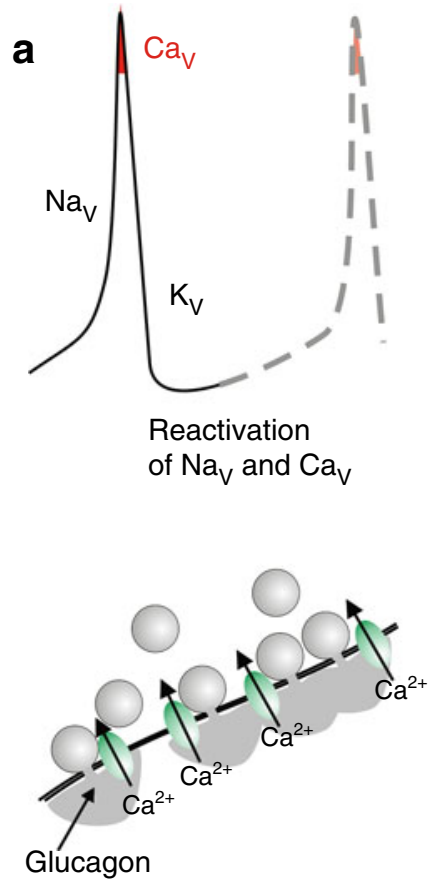

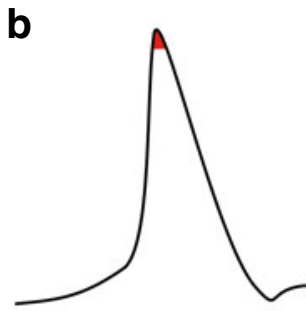

Partial block of $\mathrm{K}_{\mathrm{V}}$ reduced reactivation of $\mathrm{Na}_{\mathrm{V}}$ and $\mathrm{Ca}_{\mathrm{V}}$

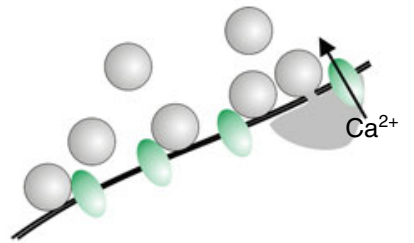

Reduced calcium entry less glucagon release
C

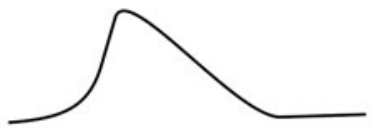

Complete block of $\mathrm{K}_{\mathrm{V}}$ no reactivation of $\mathrm{Na}_{\mathrm{V}}$ and $\mathrm{Ca}_{\mathrm{V}}$

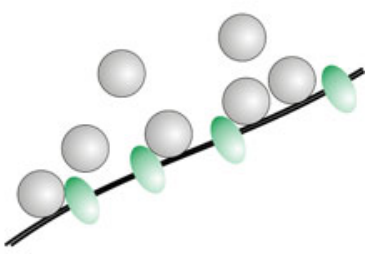

No calcium entry no glucagon release
Fig. 1 a During the upstroke of the action potential, $\mathrm{Na}_{\mathrm{V}}$-channels open. This leads to further depolarisation and takes the membrane potential into the voltage range where $\mathrm{Ca}_{\mathrm{V}}$-channels activate (highlighted in red). Calcium entry, via activation of $\mathrm{Ca}_{V}$-channels $\left(\mathrm{Ca}^{2+}\right.$; green), triggers exocytosis of glucagon (grey; lower). The opening of $\mathrm{Na}_{\mathrm{V}}$-channels and $\mathrm{Ca}_{V}$-channels is followed by activation of $\mathrm{K}_{V}$-channels. This restores the resting potential and transiently hyperpolarises the alpha cell (afterhyperpolarisation). The after-hyperpolarisation allows complete reactivation of the $\mathrm{Na}_{V}$-channels and $\mathrm{Ca}_{V}$-channels so that the next action potential (dashed) is of full size. $\mathbf{b}$ Effects of partial inhibition of the $\mathrm{K}_{\mathrm{V}^{-}}$ channels. Because the after-hyperpolarisation is reduced there is less reactivation of the $\mathrm{Na}_{V}$-channels and $\mathrm{Ca}_{V}$-channels and the amplitude of the action potential is consequently reduced. This leads to less opening of the calcium channels and fewer glucagon granules undergo exocytosis. c After complete inhibition of the $\mathrm{K}_{\mathrm{V}}$-current, there is no reactivation of the $\mathrm{Na}_{\mathrm{V}}$-channels and $\mathrm{Ca}_{\mathrm{V}}$-channels and a marked reduction of the action potential amplitude, no activation of the calcium channels and complete inhibition of glucagon release 
reconcile with any of the proposed models of intrinsic or paracrine regulation. More detailed studies of the type exemplified by the work of Spigelman et al. may help to solve this enigma.

Duality of interest The authors declare that there is no duality of interest associated with this manuscript.

\section{References}

1. Gromada J, Franklin I, Wollheim CB (2007) Alpha-cells of the endocrine pancreas: 35 years of research but the enigma remains. Endocr Rev 28:84-116

2. Rorsman P, Salehi SA, Abdulkader F, Braun M, Macdonald PE (2008) K(ATP)-channels and glucose-regulated glucagon secretion. Trends Endocrinol Metab 19:277-284

3. Miki T, Liss B, Minami K et al (2001) ATP-sensitive $\mathrm{K}^{+}$channels in the hypothalamus are essential for the maintenance of glucose homeostasis. Nat Neurosci 4:507-512

4. Gromada J, Bokvist K, Ding WG et al (1997) Adrenaline stimulates glucagon secretion in pancreatic A-cells by increasing the $\mathrm{Ca}^{2+}$ current and the number of granules close to the L-type $\mathrm{Ca}^{2+}$ channels. J Gen Physiol 110:217-228

5. Barg S, Galvanovskis J, Gopel SO, Rorsman P, Eliasson L (2000) Tight coupling between electrical activity and exocytosis in mouse glucagon-secreting alpha-cells. Diabetes 49:1500-1510

6. Leung YM, Ahmed I, Sheu L, Tsushima RG, Diamant NE, Gaisano HY (2006) Two populations of pancreatic islet alphacells displaying distinct $\mathrm{Ca}^{2+}$ channel properties. Biochem Biophys Res Commun 345:340-344

7. Rorsman P, Renstrom E (2003) Insulin granule dynamics in pancreatic beta cells. Diabetologia 46:1029-1045

8. Bokvist K, Olsen HL, Hoy M et al (1999) Characterisation of sulphonylurea and ATP-regulated $\mathrm{K}^{+}$channels in rat pancreatic Acells. Pflugers Arch 438:428-436
9. Macdonald PE, Marinis YZ, Ramracheya R et al (2007) A KATP channel-dependent pathway within alpha cells regulates glucagon release from both rodent and human islets of Langerhans. PLoS Biol 5:e143

10. Heimberg H, De Vos A, Moens K et al (1996) The glucose sensor protein glucokinase is expressed in glucagon-producing alphacells. Proc Natl Acad Sci USA 93:7036-7041

11. Ravier MA, Rutter GA (2005) Glucose or insulin, but not zinc ions, inhibit glucagon secretion from mouse pancreatic alphacells. Diabetes 54:1789-1797

12. Atwater I, Ribalet B, Rojas E (1979) Mouse pancreatic beta-cells: tetraethylammonium blockage of the potassium permeability increase induced by depolarization. J Physiol 288:561-574

13. Hoppa MB, Collins S, Ramracheya R et al (2009) Chronic palmitate exposure inhibits insulin secretion by dissociation of $\mathrm{Ca}^{2+}$ channels from secretory granules. Cell Metab 10:455-465

14. Willenborg M, Ghaly H, Hatlapatka K, Urban K, Panten U, Rustenbeck I (2010) The signalling role of action potential depolarization in insulin secretion: metabolism-dependent dissociation between action potential increase and secretion increase by TEA. Biochem Pharmacol 80:104-112

15. Spigelman A, Dai X, Macdonald PE (2010) Voltage-dependent $\mathrm{K}^{+}$ channels are positive regulators of alpha cell action potential generation and glucagon secretion Diabetologia. doi:10.1007/ s00125-010-1759-z

16. Gopel SO, Kanno T, Barg S, Weng XG, Gromada J, Rorsman P (2000) Regulation of glucagon release in mouse-cells by KATP channels and inactivation of TTX-sensitive $\mathrm{Na}^{+}$channels. J Physiol 528:509-520

17. Hille B (2001) Ion channels of excitable membranes. Sinauer, Sunderland

18. Bardoni R, Belluzzi O (1994) Modifications of A-current kinetics in mammalian central neurones induced by extracellular zinc. J Physiol 479:389-400

19. Ishihara H, Maechler P, Gjinovci A, Herrera PL, Wollheim CB (2003) Islet beta-cell secretion determines glucagon release from neighbouring alpha-cells. Nat Cell Biol 5:330-335

20. Le Marchand SJ, Piston DW (2010) Glucose suppression of glucagon secretion: metabolic and calcium responses from alphacells in intact mouse pancreatic islets. J Biol Chem 285:1438914398 